\title{
Green Building Assessment of the Desertification Rural Area in Northwest China
}

\author{
Rui LIANG ${ }^{1,2, a ~}{ }^{*}$, Bo Wen ZHANG ${ }^{2, b}$ and Qun ZHANG ${ }^{2, c}$ \\ ${ }^{1}$ Department of Environment Design, Xi'an Academy of Fine Art, Xi'an, China \\ ${ }^{2}$ Shool of Architecture, Xi'an University of Architecture \& Technology, Xi'an, China. \\ a793591446@qq.com, b764164875@qq.com, 'zhangqun029@126.com
}

Keywords:Desertification Rural Area, Northwest China,Green Buildings, Green Building Asse ssment. Abstract. Taking the rural green building as sessment system of the Northwest China as the research object, the paper would discuss regional adaptability of the green building assessment system. The paper puts forward the assessment target facing the dilemma with the development of the desertification of rural buildings in Northwest China. It presents seven assessment items such as the energy, land resources, water resources, material resources, living quality, environmental load and social effect through the methods of expert consultation, survey and technology information analysis and so on. On the above basis, assessment index system of desertification of rural green buildings in Northwest China would be put forward.

\section{Introduction}

The Desertification, which mostly refers to the ecological and land degradation resulting from man-made destruction, climate change and other factors, is defined basically as drought, semi-arid and land degradation of dry sub humid areas resulting from various factors including climate variability and human activities $^{[1]}$.

Northwest China is the main desertification distribution land of in our country. According to the statistics, more than half of the land areas of five Northwest Provinces (Xinjiang, Gansu, Qinghai, Ningxia, Shaanxi) are in the state of desertification, covering an area of approximately $56 \%$ of the total area of the desertification land ${ }^{[2]}$.(Table 1)

Typical environment characteristics of Northwest desertification area are the fragile ecological system, poor natural conditions, backward economy and social development in low level. The interconnections of backward social situation and harsh natural conditions seriously hinder the development of living environment in Northwest desertification area. More than $60 \%$ of the agricultural population of our country lives in desertification areas. Under the background of limited social natural resources, the realization of low energy consumption and high quality of rural living environment play a pivotal role for the strategy of sustainable development of our country.

Northwest desertification rural architectures are folk spontaneous buildings mostly for a long time. Although lots of experience has been accumulated and many outstanding residential types of making full use of natural resources and adapting to the natural environment have come into being, the quality of living is always difficult to meet the needs of modern life. In recent years, the Northwest desertification rural residential demand is rising with the development of society. However, a lot of construction is short of scientific and effective guidance. This not only deviates from the excellent traditional construction mode but also the quality of rural construction is low and 
energy consumption and pollution are serious, so current development of the desertification of rural green buildings in Northwest China is slow. Facing the limited resources carrying capacity of the region, the energy-efficient ecological road of the development of rural areas in Northwest China is a historical necessity. What's more, scientific and effective norms are also needed.

Table1. Desertification Area in Northwest China (Unit: million square meters)

\begin{tabular}{lcccccc}
\hline Provinces & Shaanxi & Gansu & Ningxia & Qinghai & Xinjiang & Countrywide \\
\hline Area & 3.0 & 19.9 & 2.9 & 16.7 & 104.4 & 263.62 \\
Proportion & $1.14 \%$ & $7.55 \%$ & $1.1 \%$ & $6.33 \%$ & $39.6 \%$ & $55.72 \%$ \\
\hline
\end{tabular}

\section{Purpose and Significance of The Desertification of Rural Green Buildings in Northwest China}

Scientific reasonable construction assessment system is the important condition for the construction and development of rural areas in Northwest China. Rural construction can be regulated through industry system and appropriate measures encouraging the implementation of building assessment to avoid random constructive behavior in the development of rural construction of desertification region of Northwest China ${ }^{[3]}$. At the same time, it can make the study of rural construction from qualify and quantify to provide useful feedback information for builders and users by encouraging outstanding folk buildings.

The desertification area in Northwest China is vast. The geographical environment and natural climate conditions are complicated. What's more, the regional culture is also very distinct as the multi nationality region. Under different social and natural background, rich types of traditional rural residential houses have been produced, which shows different technical and cultural characteristics. Therefore, we need to make assessment system adapting to local condition and study the green building assessment system which is suitable for the Northwest of China ${ }^{[4]}$.

\section{Research on The Desertification of Rural Green Buildings in Northwest China}

Green building has a variety of means of expression, of which is closely related to the evaluation system of green building assessment system.

The green building assessment target is closely related to the promotion mode of the system. The energy use, land system and construction way of rural construction are different from them of urban construction at the present stage of our country.

Therefore, Northwest desertification rural building assessment system design should be in the following assessment objectives. Assessment target of the desertification of rural green buildings in Northwest China has two aspects. Firstly, improve the quality of living to ensure the safe and healthy living environment ${ }^{[5]}$; secondly, encourage building technology strategy adapting to local conditions in Northwest desertification area through the design of the assessment system and the building mode should be easily in the local promotion; thirdly, encourage flexible approach to construction technology and pursue the best balance point between economic input and building performance through a combination of different economic cost of the scheme ${ }^{[6-7]}$.

\section{Assessment Hierarchy and Standards of Rural Desertification Green Building in North China}

In order to fully realize the assessment objectives of the rural green building in desertification area of Northwest China, through the analysis and comparison of expert technical advice and 
technical information, combining with the actual situation in Northwest desertification countryside, the assessment system will evaluate Northwest desertification rural dwellings from seven aspects such as energy, land resources, water resources, material resources, living quality, environmental load and social effect and so on, and on this basis, assessment index system will be established ${ }^{[8]}$.From the following tables, we can conclude that the assessment of rural green building in Northwest desertification area can not directly use the existing assessment system of green building of China .(Table 2-6 assessment standards of rural desertification green building in North China)

Table2. Assessment objective B1 Energy

\begin{tabular}{lll}
\hline \multicolumn{1}{c}{ Objectives } & \multicolumn{1}{c}{ Rules } & \multicolumn{1}{c}{ Index Interpretation } \\
\hline Energy use & $\begin{array}{l}\text { Utilization of renewable } \\
\text { resources }\end{array}$ & $\begin{array}{l}\text { Develop renewable resources according to local } \\
\text { conditions }\end{array}$ \\
\cline { 2 - 3 } & Energy structure & $\begin{array}{l}\text { Use various energy forms and establish rational } \\
\text { use of energy structure }\end{array}$ \\
Way of energy & Passive energy use & $\begin{array}{l}\text { Reduce the use of energy consumption through } \\
\text { rational planning, architectural design and } \\
\text { construction plan }\end{array}$ \\
\cline { 2 - 3 } & Active energy saving & $\begin{array}{l}\text { Save the consumption of conventional energy by } \\
\text { using the "energy saving equipment" }\end{array}$ \\
\hline
\end{tabular}

Table3. Assessment objective B2 Land resources

\begin{tabular}{lll}
\hline \multicolumn{1}{c}{ Objectives } & \multicolumn{1}{c}{ Rules } & \multicolumn{1}{c}{ Index Interpretation } \\
\hline Construction & Site environment & Protect natural ecological environment \\
\cline { 2 - 3 } site & Site choice of safety & Safety and health of living environment \\
\hline \multirow{2}{*}{$\begin{array}{l}\text { Design and } \\
\text { Plan }\end{array}$} & Overall layout & Effective and rational use of land \\
\cline { 2 - 3 } & Site greening & Greening rate is guaranteed \\
\cline { 2 - 3 } & elevation planning & Site is safe and stable complying with the terrain \\
\hline
\end{tabular}


Table4. Assessment objective B3 Water resources

\begin{tabular}{|c|c|c|}
\hline Objectives & Rules & Index Interpretation \\
\hline \multirow[t]{3}{*}{ water saving } & Water saving management & $\begin{array}{l}\text { Establish a system to ensure the long-term effect } \\
\text { of water resources utilization }\end{array}$ \\
\hline & Water saving management & $\begin{array}{l}\text { Use of water-saving facilities and water-saving } \\
\text { appliances }\end{array}$ \\
\hline & Water saving rate & $\begin{array}{l}\text { Use recycled water and rain water to reduce the } \\
\text { supply of water }\end{array}$ \\
\hline \multirow[t]{3}{*}{ Drainage } & Sewage treatment & Village sewage treatment facilities \\
\hline & Drainage system & To avoid any discharge of sewage \\
\hline & Drainage collection & Rain and sewage diversion with uniform emission \\
\hline \multirow{5}{*}{$\begin{array}{l}\text { Water } \\
\text { resource } \\
\text { utilization }\end{array}$} & Water use planning & $\begin{array}{l}\text { Comprehensive consideration of water-saving plan } \\
\text { in the planning and design stage }\end{array}$ \\
\hline & Rainwater utilization & $\begin{array}{l}\text { Economic and technical comparison is carried out } \\
\text { combining with the climatic conditions to } \\
\text { determine the water use plan }\end{array}$ \\
\hline & reclaimed water reuse & $\begin{array}{l}\text { Choose recycled water use aiming at the village } \\
\text { water target }\end{array}$ \\
\hline & Non conventional water use & $\begin{array}{l}\text { Use non conventional water sources to improve } \\
\text { the efficiency of water use and improve water } \\
\text { recycling rate }\end{array}$ \\
\hline & Drinking water safety & $\begin{array}{l}\text { To ensure the safety of drinking water and to } \\
\text { protect people's health of drinking water }\end{array}$ \\
\hline
\end{tabular}

Table5. Assessment objective B4 Material resources

\begin{tabular}{|c|c|c|}
\hline Objectives & Rules & Index Interpretation \\
\hline \multirow[t]{2}{*}{$\begin{array}{l}\text { Material } \\
\text { saving }\end{array}$} & Material saving rate & $\begin{array}{l}\text { Control the ratio of actual building material } \\
\text { consumption and computer consumption }\end{array}$ \\
\hline & Consumption control & $\begin{array}{l}\text { To achieve material saving, and control material } \\
\text { consumption during the design construction }\end{array}$ \\
\hline \multirow[t]{2}{*}{ Material reuse } & Material waste disposal & Classify the construction waste to continue to use \\
\hline & $\begin{array}{l}\text { Available material usage } \\
\text { rate }\end{array}$ & $\begin{array}{l}\text { Prolong the service life of building materials, } \\
\text { and control the total amount of building materials }\end{array}$ \\
\hline \multirow[t]{2}{*}{$\begin{array}{l}\text { Material } \\
\text { selection }\end{array}$} & obtain raw material locally & $\begin{array}{l}\text { Reduce material transportation, reduce on-site } \\
\text { processing and encourage local building materials }\end{array}$ \\
\hline & Material properties & $\begin{array}{l}\text { Control material selection and reduce resource and } \\
\text { energy consumption }\end{array}$ \\
\hline
\end{tabular}


Table6. Assessment objective B5 Residential quality

\begin{tabular}{|c|c|c|}
\hline Objectives & Rules & Index Interpretation \\
\hline \multirow[t]{4}{*}{$\begin{array}{l}\text { Comfort and } \\
\text { health }\end{array}$} & Indoor acoustic environment & $\begin{array}{l}\text { Insulate and reduce noise to ease the adverse } \\
\text { impact on the occupants }\end{array}$ \\
\hline & Indoor light environment & Ensure light environment comfortable and healthy \\
\hline & Indoor thermal environment & $\begin{array}{l}\text { Maintain reasonable structure, reasonable room } \\
\text { design and interior design temperature }\end{array}$ \\
\hline & Indoor Air Quality & $\begin{array}{l}\text { For the use of rural areas, ensure good indoor } \\
\text { ventilation environment and air quality to meet the } \\
\text { relevant standards and regulations }\end{array}$ \\
\hline \multirow[t]{2}{*}{ Safety } & Construction quality safety & Ensure construction quality safety \\
\hline & Building disaster prevention & $\begin{array}{l}\text { To protect rural life and property safety and avoid } \\
\text { natural disasters and fire. }\end{array}$ \\
\hline \multirow{2}{*}{$\begin{array}{l}\text { Reasonable } \\
\text { convenience }\end{array}$} & Space layout & $\begin{array}{l}\text { Rationally use building space to reduce the waste } \\
\text { of space }\end{array}$ \\
\hline & Use function & $\begin{array}{l}\text { Combined with the characteristics of rural } \\
\text { production and life to ensure the comfort and health }\end{array}$ \\
\hline
\end{tabular}

\section{Conclusions}

The complexity and regional sensitivity of the rural building in Northwest desertification area make the green building assessment master the development mode and the operating law of the rural green building. Therefore, the green building assessment research of the rural building in Northwest desertification area should fully consider the effect of rich natural environment, social resources, production and life style of building in Northwest China and explore the synergistic interaction between building index, and on this basis, study the assessment system with high suitability and strong operability.

\section{Acknowledge ments}

This work was supported by the Project of NSFC(51178369,51278414,51221865,51408465), China Postdoctoral Science Foundation (2014M552418).

\section{References}

[1] Longjun Ci, Xiaohui Yang. Desertification and its control in China[M].Beijing:High education press, 2010.

[2] State Forestry Administration of the People's Republic of China, Bulletin of the state of desertification of China in 2005 [R]. Beijing, 2006.

[3] Dudong, Pang Qinghua, Wuyan. Modern Comprehensive Assessment Methods and Case Selections [M]. Beijing: Tsinghua University Press, 2008.

[4] Green Building Forum: Green Building Assessment, Beijing: China Building Ind ustry Press, 2009. p277.

[5] Lin Haiyan, Cheng Zhiping, Yeling. National standard Green Building Assessment Standards GB/T50378 revised [J]. Construction Technology, 03 (2013) 64-66. 
[6] Fanyong, Huhao. The Present Application Situation and Prospect of the Ecological Building Assessment System of China, 2008, 34 (02):231-234.

[7] Song Yehao. My Opinions on Green Building Assessment Standards[J]. World Environment, 05 (2011) 24-25.

[8] Liangrui. Study on the Assessment of Ecological Residential Buildings in Northwest China [D]. Xi'an: Xi'an University Of Architecture And Technology, 2011. 